\title{
Diskresi Seponering dalam Perspektif Hukum Islam: Studi Kasus Pidana Korupsi Bibit Samad Rianto dan Chandra Martha Hamzah
}

\section{Damiri Hasan}

Program Pascasarjana

UIN Syarif Hidayatullah Jakarta, Indonesia

Email: damirihasan@ymail.com

\begin{abstract}
Abstrak
Tulisan ini mengkaji mengenai diskresi seponering. Seponering adalah hak istimewa Jaksa Agung untuk mengesampingkan perkara atau memetieskan suatu perkara karena alasan kepentingan umum setelah mendapat saran atau masukan dari institusi terkait dibidang hukum. Mensikapi tentang seponering kasus Bibit Samad Rianto dan Chandra Martha Hamzah dalam pandangan hukum pidana Islam itu adalah adil. Mengingat kedua orang tersebut sebagai pimpinan Komisi Pemberantasan Korupsi yang mempunyai tugas berat dan besar. Namun sebagai muslim memberi catatan khusus bahwa pertama, Bibit Samad Rianto dan Chandra Martha Hamzah harus mengembalikan semua uang hasil korupsi kepada negara, kedua Bibit Samad Rianto dan Chandra Martha harus minta maaf kepada publik melalui media dan berjanji tidak akan mengulangi perbuatan itu.
\end{abstract}

\begin{abstract}
This article examines the Seponering discretion. Seponering is the privilege of the Attorney General to override or freeze a court case for reasons of public interest after getting feedback from the relevant institutions in the field of law. In response about Seponering case of Bibit and Chandra Martha Hamzah in the view of Islamic criminal law is fair. Considering that the two men are the leaders of the Corruption Eradication Commission which have heavy and bulky duty. but Muslims, they are given a special note that first, Bibit and Chandra Martha Hamzah should return all the corruption money to the state, both Bibit and Chandra Martha have to apologize to the public through the media and vowed not to reiterate the act.
\end{abstract}

Intizar, Vol. 22, No. 1, 2016 
Keywords: Seponering, Islamic Law

Kata diskresi berasal dari bahasa Inggris, yaitu discretion yang secara etimologi berarti kebijaksanaan atau keleluasaan. ${ }^{1}$ Sedangkan pengertian diskresi secara istilah adalah keputusan hakim yang telah keluar dari apa yang telah ditentukan oleh undang-undang. ${ }^{2}$ Pendapat lain mengatakan bahwa pengertian diskresi adalah "Ability to choose wisely or to jugle one self (kemampuan untuk memilih secara bijaksana atau mempertimbangkan bagi diri sendiri)". 3

Pendapat yang berbeda mengatakan bahwa kata diskresi berasal dari bahasa belanda yakni discretionair yang secara istilah berarti kebijaksanaan dalam wewenangnya untuk memutuskan suatu tindakan berdasarkan ketentuan peraturan perundang-undangan atau hukum yang berlaku. Tetapi atas dasar kebijaksanaan yang berhubungan erat dengan keadilan. Pendapat lain mengatakan bahwa diskresi adalah suatu kebebasan untuk mengambil suatu tindakan berupa keputusan dalam setiap situasi yang dihadapi menurut pendapatnya sendiri sesuai dengan otoritas yang dimiliknya. ${ }^{4}$

Pendapat yang berbeda mengatakan bahwa "Discreation is power authority conferred by law to action an the basic of judge of conscience, and its use is more than idea of morals than law (Suatu kekuasaan atau wewenang yang dilakukan berdasarkan hukum atas pertimbangan adanya keyakinan, serta lebih memerlukan pertimbangan moral daripada pertimbangan hukum). ${ }^{5}$

Dalam rancangan undang-undang administrasi pemerintahan dikatakan bahwa diskresi adalah kepentinngan dan/atau tindakan yang dilakukan oleh pejabat yang berwenang untuk mengatasi atau menyelesaikan persoalan konkrit yang dihadapi dalam penyelenggaraan pemerintahan, dalam hal peraturan perudang-undangan memberikan pilihhan tidak mengatur, tidak lengkap, atau tidak jelas, dan/atau adanya stagnasi pemerintahan. ${ }^{6}$

Kata deponeering berasal dari bahasa Belanda yaitu deponer yang secara etimologi berarti menyimpan sesuatu untuk tidak digarap, sedangkan menurut kamus hukum Belanda-Indonesiadeponeering berasal dari kata deponeren yang secara etimologi berarti mengesampingkan (perkara) memetieskan, atau mendeponer. Dari kedua pengertian tersebut berarti kata deponeering identik dengan asas oportunitas. Sehingga, pada prinsipnya asas deponeering identik dengan asas oportunitas. Oleh karena itu, pengertian dari asas deponering adalah penuntut umum tidak wajib menuntut seseorang yang melakukan tindak pidana jika menurut pertimbangannya tidak merugikan kepentingan umum, artinya

Intizar, Vol. 22, No. 1, 2016 
seorang jaksa sebagai penuntut umum berdasarkan undang-undang tidak harus mengajukan perkara pidana itu ke pengadilan meskipun perkara tersebut memenuhi unsur-unsur delik pidana. ${ }^{7}$

Dalam kamus bahasa Belanda-Indonesia lainnya bahwa deponeering berasal dari kata deponeren yang secara etimologi berarti menitipkan, memetieskan suatu perkara, mendaftarkan, mengendapkan, dan menyimpan. ${ }^{8}$ Sedangkan kata seponering berasal dari kata seponeren yang secara etimologi berarti menyampingkan suatu perkara, menyimpan atau mendep sebuah surat, mendep sebuah perkara, dan tidak menuntutnya. ${ }^{9}$

Menurut kamus bahasa Latin, kata deponeering secara etimologi artinya deponeering, sedangkan seponering secara etimologi artinya seponering. Kata pengesampingan perkara artinya waiver casibus, sedangkan mengesampingkan perkara artinya exclusionemcausae. Mengesampingkan perkara demi kepentingan umum artinya excluso casurei publicae causa aperienda, sedangkan Jaksa Agung mengesampingkan perkara demi kepentingan umum artinya Advocatus excludontur causae communi bono publico. ${ }^{10}$

Dalam pengertian lain deponeering adalah asas oportunitas yakni, asas hukum yang memberikan wewenang kepada penuntut umum untuk menuntut atau tidak menuntut dengan atau tanpa syarat seseorang atau korporasi yang telah mewujudkan delik demi kepentingan umum. Dengan kata lain bahwa penuntut umum sebagai aparatur negara sekaligus penegak hukum mempunyai hak prerogratif yang diberikan oleh undang-undang untuk menuntut atau tidak menuntut perkara tersebut sesuai dengan tugas dan wewenangnya. ${ }^{11}$

Kata deponeering bentuk kata dari deponeren yang berarti menyerahkan, melaporkan, atau mendaftarkan. Hal ini ditemukan dalam ranah hukum dagang atau hukum bisnis, hukum administrasi, dan hukum perpajakan. Misalnya, suatu perusahaan yang telah memperoleh hak merek dari institusi yang berwenang, dan perusahaan itu ingin mendaftarkan nama hak merekanya itu ke institusi yang berwenang (Het bedrijf wilde zijn deponeren). Namun dalam pengertian bahasa yang digunakan sehari-hari, deponeren bisa berarti membuang. Maksudnya, suatu perkara tidak perlu diproses menurut prosedur hukum acara pidana namun, perkara itu ditiadakan. ${ }^{12}$

Kata deponeering sebenarnya dalam menggunaan bahasa hukum, penggunaan kata itu tidak tepat apabila dilihat dari kata aslinya yang berbahasa Belanda. Karena kata aslinya dalam bahasa Belanda adalah seponering yakni bentukan dari kata seponerenatau sepot yang berarti menyampingkan (terzijde 
leggen), tidak menuntut (neit vervalgen), sebagaimana diatur dalam Kitab Undang-Undang Hukum Pidana Belanda (Het nederlands strafproces recht). Maksudnya adalah tidak melanjutkan atau mengesampingkan terhadap tersangka ke sidang pengadilan, namun karena perkembangan hukum yakni dengan berlakunya asas oportunitas sesuai dengan ketentuan dalam hukum acara pidana, sehingga pelaku tindak pidana tidak cukup bukti untuk diajukan ke pengadilan. ${ }^{13}$

Seponering adalah hak istimewa Jaksa Agung untuk mengesampingkan perkara atau memetieskan suatu perkara karena alasan kepentingan umum setelah mendapat saran atau masukan dari institusi terkait di bidang hukum. Dalam statmen lain mengatakan bahwa baik istilah deponeering maupun seponeering, keduanya mempunyai pengertian yang sama benarnya dan istilah tersebut sudah menjadi bahasa hukum sehari-hari yang dipergunakan diberbagai media baik media cetak, elektronik, maupun media lainnya. Sehingga penggunaan kata deponeering maupun kata seponeering tidak perlu dipersoalkan. ${ }^{14}$

Adanya seponeering berlandaskan pada prinsip dasar penegakan hukum Islam. Prinsip dasar tersebut, yakni: mudah dan tidak memberatkan, mengutamakan kepentingan umum, serta menegakkan keadilan terhadap setiap orang. ${ }^{15}$ Prinsip tersebut harus ditaati dan dilaksanakan oleh penegak hukum dengan sangat hati-hati, teliti, dan adil berdasarkan ketentuan yang ada pada AlQur'an dan Sunnah. ${ }^{16}$ Prinsip Pertama, mudah dan tidak memberatkan. Allah swt. berfirman dalam surat al-Baqarah ayat 185 yang artinya: .... "Allah menghendaki kemudahan bagimu, dan tidak menghendaki kesukaran bagimu. Hendaklah kamu mencukupkan bilangannya dan mengagungkan Allah atas petunjuk-Nya yang diberikan kepadamu, agar kamu bersyukur". ${ }^{17}$ Dalam ayat lain Allah swt. berfirman yakni dalam surat al-Maidah ayat 6 yang artinya: ....."Allah tidak hendak menyulitkan kamu, tetapi Dia hendak membersihkan kamu dan menyempurnakan ni'mat-Nya bagimu, supaya kamu bersyukur". ${ }^{18}$

Dari ayat di atas dapat dijelaskan bahwa Allah swt. selalu memberi kemudahan kepada setiap hambanya, bukan justru malah sebaliknya Allah swt. sama sekali tidak akan mempersulit hambanya. Hal ini sesuai dengan sifat Allah swt. yang Maha Rahman dan Maha Rahim. Kesemuanya itu semata-mata agar hambanya selalu bersyukur kepada Allah swt. terhadap nikmat yang telah diberikannya. Apabila hambanya mau bersyukur, maka niscaya Allah akan menambah nikmat tersebut. Namun, apabila hambanya kufur niscaya Hamba-Nya mendapat siksa yang nyata.

Intizar, Vol. 22, No. 1, 2016 
Kaitan dengan prinsip dasar berlakunya hukum Islam yang mudah dan tidak memberatkan di atas, Allah swt. pun sekali-kali tidak memberikan beban dan tanggungjawab kepada hambanya. Kecuali atas dasar hak prerogratif Allah swt. bahwa hambanya sudah mampu untuk diserahi tugas dan tanggungjawab untuk melaksanakan amanah. Hal ini ditegaskan dalam al-Qur'an surat al Baqarah ayat 286 yang artinya: "Allah tidak membebani seseorang melainkan sesuai dengan kemampuannya, ia mendapat pahala (dari kebajikan) yang diusakannya dan ia mendapat siksa (dari kejahatan) yang dikerjakannya. (Mereka berdoa Ya Tuhan kami janganlah Engkau hukum kami jika kami lupa atau kami bersalah. Ya Tuhan kami, janganlah Engkau bebankan kepada kami beban yang berat sebagaimana Engkau bebankan kepada orang-oarnag sebelum kami. Ya Tuhan kami jangan Engkau pikulkan kepada kami apa yang tak sanggup kami memikulnya. Beri maaflah kami dan rahmatilah kami. Engkau penolong kami, maka tolonglah kami terhadap kaum yang kafir". 19

Dari ayat tersebut dapat diambil suatu pengertian bahwa seseorang tidak akan diberi tugas dan tanggungjawab oleh Allah swt sesuai dengan tingkat atau kadar kemampuan orang tersebut. Artinya, suatu tugas dan tanggungjawab tidak akan dapat dilaksanakan dengan baik manakala mereka tidak mampu melaksanakan tugas itu dan mempertanggungjawabkannya.

Prinsip kedua adalah mengutamakan kepentingan umum. Hal ini berarti penegakkan hukum lebih diutamakan demi untuk kepentingan orang banyak, kepentingan masyarakat yang harus dikedepankan bukan kepentingan perorangan yang harus diutamakan dan apabila kemaslahatan umat tidak didahulukan. Maka mala petaka bagi ummat manusia akan terjadi. Adapun prinsip kemaslahatan umat adalah tidak membedakan ras, suku, agama, profesi dan bersifat abadi, mutlak, serta universal. $^{20}$

Hal ini telah disebutkan dalam al-Qur'an surah al-Anbiya ayat 107 menegaskan artinya : "Dan tiadalah Kami mengutus kamu melainkan untuk (menjadi) rahmatbagi semesta alam”. ${ }^{21}$ Demikian al-Qur'an surat al-Saba' ayat 28 yang artinya: "Dan Kami tidak mengutus kamu, melainkan kepada umat manusia seluruhnya sebagai pembawa berita gembira dan sebagai pemberi peringatan, tetapi kebanyakan manusia tiada mengetahuinya”. ${ }^{22}$

Kepentingan umum juga berarti kepentingan bangsa dan negara serta kepentingan bersama dari rakyat dengan memperhatikan segi sosial, politik, dan hankamnas, atas dasar asas pembangunan nasional, dengan mengindahkan ketahanan nasional serta wawasan nusantara, menyangkut hajat kepentingan orang

Intizar, Vol. 22, No. 1, 2016 
banyak, bahkan termasuk orang yang telah meninggal dengan kata lain hajat semua orang. ${ }^{23}$ Dilihat dari segi yuridis, kepentingan umum dapat berlaku sepanjang kepentingan tersebut tidak bertentangan dengan hukum positif, maupun hukum yang tumbuh hidup dan berkembang dalam masyarakat yang penerapannya bersifat kasuistis. ${ }^{24}$

Prinsip ketiga adalah menegakkan keadilan terhadap semua orang, yakni dalam penegakan hukum bukan hanya sekedar mencari keadilan. Namun benarbenar adil termasuk penegakan hukum terhadap musuh Islam, yaitu dalam keadaan perang sekalipun. ${ }^{25}$

Hal ini diperintahkan oleh Allah swt dalam surat an Nahl ayat 90 yang artinya: "Sesungguhnya Allah menyuruh kamu berlaku adil dan berbuat kebajikan memberi kerabat dan melarang dari perbuatan keji, kemungkaran, dan permusuhan. Dia memberi pengajaran kepadamu agar kamu dapat mengambil pelajaran." 26

Penegakan Hukum Islam juga melindungi hak perorangan dan masyarakat dimanapun mereka berada. Sehingga semua orang merasa hidup dengan tenang terhadap dirinya, kehormatan, harta, dan hak-haknya, tanpa membedakan antara muslim dan non muslim. ${ }^{27}$

Suatu persoalan dalam memahami diskresi dalam hukum Islam, yakni apakah dalam memahami diskresi itu sama dengan memahami ijtihad. Apabila pemahaman diskresi itu sama dengan ijtihad, maka persoalan itu tidak mungkin terjadi. Namun seandainya pemahaman diskresi itu tidak sama dengan ijtihad, maka persoalan akan timbul yakni, Pertama dasar hukum diskresi itu sendiri, apakah al-Qur'an atau sunnah, Kedua upaya diskresi itu menjadi suatu kewajiban atau hanya sunnah saja, dan Ketiga apakah diskresin itu bagian dari ijtihad.

Apabila diskresi itu sama dengan ijtihad, maka sudah jelas bahwa tindakan ijtihad itu sangat dianjurkan dalam Islam sebagaimana dikisahkan dalam hadis yang artinya: Ketika Nabi saw. mengutus Sahabat Muadz bin Jabal ke Yaman sebagai hakim Nabi bertanya kepadanya: "Bagaimana cara kamu menghukumi suatu masalah hukum?" Muadz menjawab: Saya akan putuskan dengan apa yang dalam kitabullah (al-Quran). Nabi bertanya lagi: "Apabila tidak kamu temukan dalam al-Quran?” Muadz menjawab: Dengan sunnah Rasulullah. Nabi bertanya lagi: "Kalau tidak kamu temukan?" Muadz menjawab: Saya akan berijtihad dengan pendapat saya. Lalu Nabi bersabda: Segala puji bagi Allah yang telah memberi pertolongan pada utusannya Rasulullah. (H.R. Imam al-Tirmidhi). ${ }^{28}$

Intizar, Vol. 22, No. 1, 2016 
Dari hadis itu dapat dipahami bahwa setiap orang menghadapi suatu masalah yang memerlukan penyelesaian. Padahal apabila mengacu pada al-Qur'an dan sunnah belum ada rujukannya. Maka sebagai orang Islam diwajibkan untuk berijtihad dengan berupaya mencurahkan segala daya nalar untuk menyelesaikan masalah tersebut.

Istilah hukum pidana Islam yang dalam kamus bahasa Arab disebut dengan jinayah, yang berarti perbuatan dosa, kejahatan, undang-undang pidana, atau undang-undang tentang kejahatan ${ }^{29}$. Sedangkan menurut pengertian lain bahwa menurut arti bahasa jinayah merupakan nama bagi suatu perbuatan jelek seseorang, dan menurut istilah jarimah adalah perbuatan yang diharamkan syara', baik perbuatan tersebut mengenai jiwa, harta benda, maupun selain harta dan benda, dan istilah perkara pidana Islam yang disebut dengan jarimah yang menurut para fuqaha berarti "larangan-larangan syara' yang diancam dengan hukuman had atau ta'zir". ${ }^{30}$ Penerapan hukum pidana Islam dilakukan sangat selektif, teliti, dan hati-hati. Sehingga hasil akhir akan memenuhi rasa keadilan bagi mereka yang mencarinya.

Pada prinsipnya perbuatan manusia dapat dikategorikan sebagi jinayah jika perbuatan-perbuatan tersebut di ancam hukuman. Karena larangan-larangan tersebut dari syara', maka larangan tersebut hanya ditujukan kepada orang-orang yang berakal sehat dan orang yang berakal sehat saja yang dapat menerima panggilan (khitab). Sedangkan perbuatan yang dilakukan anak kecil atau orang gila tidak dapat dikategorikan sebagai jinayah, karena tidak dapat menerima khitab atau memahami taklif.

Atas dasar tersebut dapat ditarik unsur atau rukun jinayah, unsur atau rukun jinayah tersebut adalah: Pertama, adanya nash yang melarang perbuatan tertentu yang disertai ancaman hukuman atas perbuatan tersebut, unsur ini dikenal dengan unsur formal (al-rukn al-syar'i). Kedua, adanya perbuatan yang membentuk jinayah, baik melakukan perbuatan yang dilarang atau meninggalkan perbuatan yang diharuskan. Unsur ini dikenal dengan unsur material (al-rukn almadi). Ketiga, pelaku kejahatan adalah orang yang dapat menerima khitab atau dapat memahami taklif. Unsur ini dikenal dengan unsur material (al-rukn aladabi). ${ }^{31}$

Pendapat lain mengatakan bahwa yang termasuk unsur jarimah adalah sebagai berikut: Pertama, unsur formal, yakni adanya undang-undang atau nas, artinya setiap perbuatan tidak dianggap melawan hukum dan pelakunya tidak dapat di pidana kecuali adanya nas atau undang-undang yang mengaturnya. Dalam

Intizar, Vol. 22, No. 1, 2016 
hukum positif masalah ini dikenal dengan istilah asas legalitas, yaitu suatu perbuatan tidak dapat dianggap melawan hukum dan pelakunya tidak dapat dikenai sanksi sebelum adanya peraturan yang mengundangkannya. Dalam syariat Islam lebih dikenal dengan istilah al-rukn al-shar'i. Kaidah yang mendukung unsur ini adalah "tidak ada perbuatan yang dianggap melanggar hukum dan tidak ada hukuman yang dijatuhkan kecuali adanya ketentuan nas". Kaidah lain menyebutkan "tiada hukuman bagi perbuatan mukallaf sebelum adanya ketentuan nas". Kedua, unsur materiil yakni sifat melawan hukum, artinya adanya tingkah laku seseorang yang membentuk jarimah, baik dengan sikap berbuat maupun sikap tidak berbuat. Unsur ini dalam hukum pidana Islam disebut dengan al-rukn al-madi. Ketiga, unsur moril yakni pelakunya mukallaf, artinya pelaku jarimah adalah orang yang dapat dimintai pertanggungjawaban pidana terhadap jarimah yang dilakukannya. Dalam syariat Islam unsur moril disebut dengan ar-rukn aladabi. Orang yang melakukan tindak pidana dapat dipersalahkan dan dapat disesalkan, artinya bukan orang gila, bukan anak-anak dan bukan karena dipaksa atau karena pembelaan diri. ${ }^{32}$

Proses penanganan jarimah baik jarimah had, jarimah qisas diyyat, jarimah ta'zir, maupun jarimah kiffarat, mengacu kepada bagaimana penanganan jarimah yang pernah dilaksanakan pada masa Rasulullah saw. yakni di era pertumbuhan hukum Islam, dan Khulafaur Rasyidin yakni di era perkembangan/ periode remaja hukum Islam (Abu Bakar, 'Umar, 'Usman, dan Ali, serta masa Tabi'in), serta di era kedewasaan hukum Islam (timbulnya mazhab). ${ }^{33}$

\section{Seponering dalam Perspektif Hukum Islam}

Hukum Islam menjunjung tinggi terwujudnya keadilan. Hal ini merupakan salah satu prinsip penegakan hukum, yakni menegakkan keadilan terhadap setiap orang. Dalam prinsip penegakan hukum Islam, tidak dikenal istilah tebang pilih dan kekebalan hukum. Artinya, setiap orang yang melakukan pelanggaran hukum harus dihukum, setiap orang yang melakukan perbuatan kejahatan harus mempertanggungjabkan perbuatannya itu. Apabila dikaitkan dengan prinsip penegakan hukum pidana nasional yang berbunyi "Setiap orang yang melanggar hukum harus dihukum kecuali ada alasan pemaaf atau alasan pembenar", maka prinsip tersebut tidak sesuai.

Ada perbedaan yang mendasar pengertian pemaaf dalam hukum Islam dan maaf pada hukum pidana nasional. Pertama, dilihat dari otoritasnya, dalam hukum pidana Islam pemaafan diberikan oleh ahli waris korban kepada pelaku jarimah. 
Sedangkan dalam hukum pidana nasional pemaafan diberikan oleh undang-undang kepada sesorang yang melakukan tindak pidana karena mengalami gangguan jiwa. Kedua, dilihat dari penerapan hukumnya bahwa pemberian maaf dalam hukum Islam tidak menghilangkan hukuman kepada pelaku jarimah, namun hanya pengalihan hukuman. Sebagai contoh, sesorang yang melakukan jarimah qisos pembunuhan, apabila dimaafkan oleh ahli waris korban, maka pelaku jarimah harus membayar diyat atau tebusan. Sedangkan dalam hukum pidana nasional, apabila sesorang yang melakukan tindak pidana pembunuhan karena mengalami gangguan jiwa, maka keputusannya diserahkan kepada hakim, dan biasanya hakim memerintahkan kepada jaksa untuk memasukkan pelaku ke rumah sakit jiwa guna menjalani rehabilitasi jiwa.

Alasan pembenar, Pertama, karena melaksanakan tugas negara. Seseorang yang melaksanakan tugas negara baik dalam hukum Islam maupun hukum pidana nasional. Pelaku jarimah tidak dapat dipidana karena mereka melakukan jarimah untuk melaksanakan tugas negara. Sehingga jarimah itu hapus karena melaksanakan tugas itu. Contohnya, seseorang melakukan pembunuhan sebagai algoco terhadap seseorang yang telah divonis hukuman mati oleh hakim yang telah mempunyai kekuatan hukum tetap, maka karena perbuatannya membunuh orang itu, mereka tidak dapat dipidana. Contoh lain, seorang dokter yang karena alasan kesehatan, mereka harus menghilangkan sebahagian organ tubuh si pasien, dokter tersebut tidak dapat dipidana, karena melaksanakan tugas berdasarkan undang-undang. Kedua, karena pembelaan, seseorang yang melakukan tindak pidana kerena pembelaan, maka ia tidak dapat di pidana, hal ini malah justru diperintahkan oleh Allah Swt. dalam al-Qur'an surat al-Baqarah ayat 194 yang artinya: “...barang siapa menyerang kepadamu, maka seranglah ia sebagaiman ia menyerang kepadamu ....”. Ketentuan tersebut diperkuat oleh hadist nabi yang artinya: "Tolonglah saudaramu baik sebagai penganiaya maupun sebagai teraniaya”.

Dalam hukum Islam setiap orang kedudukannya sama dalam hukum, tidak memandang status sosial, jenis kelamin, dan sebagainya, kecuali dalam hal tertentu. Setiap orang tidak ada yang kebal hukum, tidak ada seseorang yang tidak tersentuh oleh hukum apabila ia melanggar hukum baik mereka sebagai orang awam atau sebagai penegak hukum sekalipun. Hukum Islam bagaikan senjata yang siap dibidikkan kemana saja ke segala penjuru termasuk yang memegang senjata itu sendiri. Suatu hal yang mustahil apabila hukum Islam itu tajam ke

Intizar, Vol. 22, No. 1, 2016 
bawah dan tumpul ke atas serta ke samping, hal ini tidak sesuai dengan prinsip penegakan hukum Islam.

Apabila dilihat dari sejarah penegakan hukum pidana Islam dari periode pertumbuhan hukum Islam, periode perkembangan hukum Islam, periode kedewasaan hukum Islam, periode kejenuhan hukum Islam, sampai dengan masa kebangkitan hukum Islam, hingga dewasa ini belum pernah dijumpai penegakan hukum Islam dengan kebijakan seponering, dengan alasan Pertama, norma-norma hukum tentang jarimah hudud dan jarimah qisos materi muatannya yang terkandung dalam nash baik dalam al-Qur'an mapun hadist, merupakan ketentuan yang mutlak dan pasti. Artinya, ketentuan tersebut tidak ada seorang pun baik kapasitasnya sebagai pribadi maupun sebagai penguasa mempunyai otoritas untuk merubah atau mengganti baik sebagian atau seluruhnya terhadap ketentuan isi yang terkandung dalam al-Qur'an dan hadist tersebut. Kedua, al-Qur'an adalah kitab suci yang terakhir yang diturunkan oleh Allah swt. dan tidak ada kitab suci setelah itu yang berasal dari wahyu. Sedangkan nabi Muhammad saw. adalah rasul terakhir dan tidak ada rasul setelah itu.

Penegakan hukum Islam terhadap penerapan jarimah ta'zir sangat elastis tergantung kepada siapa yang berkuasa, termasuk norma hukum dan sanksinya sewaktu-waktu dapat diubah. Norma hukum dan sanksi hukumnya bersifat dinamis artinya dapat menyesuaikan dengan dinamika hukum yang berkembang di masyarakat. Akan tetapi, penegakan hukum terhadap selain jarimah ta'zir merupakan harga mati yang tidak dapat ditawar-tawar lagi.

Kebijakan seponering dalam sejarah penegakan hukum Islam tidak pernah dilakukan oleh penguasa yang mmenerapkan hukum Islam terhadap jarimah selain jarimah ta'zir. Hal itu mengacu pada penegakan hukum yang telah dilakukan oleh Rasulullah saw dan para sahabat. Sedangkan kebijakan seponering pada jarimah ta'zir dapat dilakukan. Hal itu mengacu pula pada penegakan hukum jarimah ta'zir pada masa sahabat.

Pada prinsipnya penegakan hukum berupa seponering dalam hukum Islam dapat dilakukan dalam ranah jarimah ta'zir. Akan tetapi, kebijakan seponering tersebut harus diperhitungkan dengan masak-masak akibat yang mungkin terjadi setelah kebijakan seponering itu dilakukan. Yakni penguasa harus mempertimbangkan lebih besar mana antara manfaat dengan mahdharat-nya apabila jarimah tersebut dilakukan seponering. Dengan kata lain bahwa kebijakan seponering dilakukan semata-mata untuk kepentingan umum.

Intizar, Vol. 22, No. 1, 2016 


\section{Seponering Perkara Pidana Bibit Samad Rianto dan Chandra Martha Hamzah dalam Perspektif Hukum Pidana Islam}

Tindakan pengesampingan perkara atau deponeering atas perkara Bibit Samad Rianto dan Chandra Martha Hamzah apabila ditinjau dari aspek hukum Islam sangat-sangat mencederai rasa keadilan yang selama ini dijunjung tinggi, oleh setiap hamba Allah swt. sebagai penegak keadilan.

Apabila ditelusuri dari awal timbulnya jarimah perkara Bibit dan Chandra, maka ada dua tindak pidana yang disangkakan kepada mereka, yakni, pertama, bahwa mereka diduga menerima suap dengan melanggar pasal 12 huruf e, Undang-Undang Nomor 31 Tahun 1999, jo. Undang-Undang Nomor 20 Tahun 2001, dan kedua, diduga telah melakukan tindak pidana penyalahgunaan kekuasaan sebagaimana diatur dalam pasal 421 KUHAP. Namun, apabila dikaji lebih cermat tindak pidana yang disangkakan tersebut, bila ditinjau dari aspek hukum pidana Islam, maka secara komulatif mereka telah menyalahgunakan kekuasaan dengan menerima suap. Sehingga jarimah atau tindak pidana yang disangkakan termasuk jarimah ta'zir, yakni norma perbuatannya sudah ditentukan oleh nash. Akan tetapi, ancaman hukumannya ditentukan oleh manusia.

Dalam hukum pidana Islam istilah suap disebut rishwah, yang artinya uang suap. Sedangkan yang memberi uang suap disebut 'Rashi', dan orang yang menerima suap disebut 'Murtashi' ${ }^{34}$ Apabila dilihat dari segi hukumya bahwa tindakan orang yang melakukan perbuatan suap adalah dilarang oleh Allah Swt. sebagimana disebut firman-Nya dalam al-Qur'an surat al-Baqarah ayat 188 yang artinya: "Dan janganlah kalian memakan harta di antara kalian dengan cara yang batil, dan janganlah kamu membawa urusan harta itu kepada hakim, supaya kamu dapat memakan sebahagian daripada harta benda orang lain itu dengan (jalan berbuat) dosa padahal kamu mengetahui."35 Selain itu juga, surat alMaidah ayat 42 menegaskan yang artinya : "Mereka itu adalah orang-orang yang suka mendengar cerita bohong, banyak memakan yang haram, (seperti uang sogokan dan lain sebagainya). Jika mereka (orang Yahudi) datang kepadamu (untuk minta putusan), maka putuskanlah (perkara itu) di antara mereka atau atau berpalinglah dari mereka. Jika kamu berpaling dari mereka, maka mereka tidak akan memberi mudorat kepadamu sekalipun. Dan jika kamu memutuskan perkara mereka, maka putuskanlah (perkara itu) diantara mereka dengan adil, sesungguhnya Allah menyukai orang-orang yang adil". 36

Di samping itu, Rasulullah saw. telah melarang tindakan suap seperti dalam sabdanya: "Rasulullah melaknat orang yang menyuap dan orang yang

Intizar, Vol. 22, No. 1, 2016 
disuap dalam masalah hukum" (H.R. al-Tirmidhi). ${ }^{37}$ Sedangkan dalam hadis lain Rasulullah saw. yang artinya: "Rasulullah melaknat pemberi suap, penerima suap, dan perantaranya" (H.R. al-Tirmidhi). ${ }^{38}$

Hadist lain yang senada dengannya menegaskan: Barangsiapa di antara kalian yang kami tugaskan untuk suatu pekerjaan (urusan), lalu dia menyembunyikan dari kami sebatang jarum atau lebih dari itu, maka itu adalah ghulul (belenggu, harta korupsi) yang akan dia bawa pada hari kiamat”. ('Adiy) berkata : Maka ada seorang lelaki hitam dari Anshar berdiri menghadap Nabi saw., seolah-olah aku melihatnya, lalu dia berkata,"Wahai Rasulullah, copotlah jabatanku yang engkau tugaskan." Nabi saw. bertanya, "Ada apa gerangan?" Dia menjawab, "Aku mendengar engkau berkata demikian dan demikian (maksudnya perkataan di atas, Pen.)." Beliau saw. pun berkata,"Aku katakan sekarang, (bahwa) barangsiapa di antara kalian yang kami tugaskan untuk suatu pekerjaan (urusan), maka hendaklah dia membawa (seluruh hasilnya), sedikit maupun banyak. Kemudian, apa yang diberikan kepadanya, maka dia (boleh) mengambilnya. Sedangkan apa yang dilarang, maka tidak boleh.”(H.R. Imam Muslim). ${ }^{39}$

Dari ketentuan di atas, baik al-Qur'an maupun hadist, tidak ada norma hukum yang mengatur ancaman hukuman atau sanksi hukum pidana kepada si pelaku jarimah, hal ini menjadi ranah hukum dan ijtihad manusia. Oleh karena itu, ancaman hukuman terhadap tindak pidana suap yang disangkakan kepada tersangka Bibit dan Chandra, adalah ancaman tindak pidana korupsi, dan ancaman hukuman ini tidak bertentangan dengan hukum pidana Islam. ${ }^{40}$

Penegakan hukum pidana Islam apabila dikaitkan dengan deponeering kasus Bibit dan Chandra, sama sekali tidak sesuai dengan hukum pidana Islam. Tindakan deponeering oleh jaksa agung justru mencederai keadilan. Apabila pemegang amanah di negeri ini akan menegakkan keadilan sudah seharusnya tindakan deponeering tidak dilakukan. Penegakan hukum demi keadilan telah dicontohkan oleh nabi Muhammad saw. ketika ada isu bahwa Siti Fatimah binti Muhammad saw. diisukan mencuri kalung. Maka dengan tegas Muhammad saw. mengatakan bahwa apabila Siti Fatimah Binti Muhammad benar-benar terbukti mencuri kalung, niscaya aku sendiri yang akan memotong tangannya. Hal ini menunjukkan bahwa penegakan hukum demi keadilan merupakan harga mati, tidak tebang pilih, dan tidak boleh ditawar lagi. Oleh karena itu, penetapan deponeering kasus Bibit dan Chandra harus dicabut, dan selanjutnya perkaranya dilimpahkan ke pengadilan. ${ }^{41}$

Intizar, Vol. 22, No. 1, 2016 
Pada prinsipnya dalam hukum Islam tidak mengenal deponering, namun apabila kita cermati lebih dalam, maka ada suatu celah hukum yang hampir mirip dengan deponeering, akan tetapi bukan mengesampingkan perkara, tapi mengesampingkan vonis, seperti pada delik pembunuhan atau jarimah qisas. Kaitan dengan jarimah qisas firman Allah di al-Qur'an surat al-Baqarah ayat 178 mengatakan : "Hai orang-orang yang beriman diwajibkan atas kamu qisos berkenaan dengan orang-orang yang dibunuh, orang merdeka dengan orang merdeka, hamba dengan hamba, dan wanita dengan wanita. Maka barang siapa yang mendapat sesuatu pemaafan dari saudaranya, hendaklah yang memaafkan hendaklah mengikuti dengan cara yang baik dan hendaklah (yang diberi maaf) membayar (diyat) kepada yang memberi maaf dengan cara yang baik (pula) yang demikian itu adalah suatu keringanan dari Tuhan kamu dan suatu rahmat. Barang siapa yang melampaui batas sesudah itu, maka baginya siksa yang sangat pedih. ${ }^{42}$

Firman Allah tersebut diperjelas dengan hadist nabi yang Artinya: "Barangsiapa yang anggota keluarganya dibunuh, maka dia boleh memilih mana yang terbaik di antara dua pilihan: dia dapat menerima uang diyat, ataupun dia menuntut balas (membunuh si pembunuh)." (H.R. Imam al-Tirmidhi) ${ }^{43}$. Demikian juga hadis yang semakna dengannya menyebutkan: "Barangsiapa yang anggota keluarganya dibunuh, maka dia boleh memilih: dia menuntut balas (membunuh si pembunuh), atau dia memaafkannya (memaafkan si pembunuh) sambil menerima uang diyat."(H.R. Imam al-Tirmidhi) ${ }^{44}$

Ketentuan dari ayat al-Qur'an dan hadist nabi tersebut ada celah hukum yang bisa disimpangi yakni dengan mengesampingkan vonis, bukan mengesampingkan perkara. Pada prinsipnya dalam hukum Islam apabila seseorang membunuh seseorang, maka mereka harus dibunuh dengan kata lain nyawa harus dibalas dengan nyawa. Namun, apabila ahli waris korban memaafkan pelaku jarimah. Maka bagi ahli waris mempunyai hak perdata yakni meminta diyyat atau pengganti, untuk setiap satu nyawa diganti dengan 100 (seratus) ekor unta. ${ }^{45}$

Pengesampingan perkara kasus Bibit Samad Rianto dan Chandra Martha Hamzah bila dimisalkan dengan pengesampingan vonis hakim tidak tepat. Karena vonis hakim harus melalui proses persidangan, akan tetapi kalau pengesampingan perkara tidak melalui proses persidangan. Apabila penyelesaian kasus Bibit Samad Rianto dan Chandra Martha Hamzah akan diselesaikan secara hukum pidana Islam. Maka harus melalui proses persidangan. Setelah proses persidangan selesai dan hakim memutuskan bahwa Bibit Samad Rianto dan Chandra Martha Hamzah tidak bersalah. Maka mereka bebas, tapi kalau bersalah

Intizar, Vol. 22, No. 1, 2016 
tentunya vonis bersalah dan hukumannya harus dijatuhkan. Persoalannya "apakah vonis hakim yang manyatakan bersalah itu bisa diganti dengan diyat"dan "apakah itu adil menurut pandangan hukum Islam" masalah ini perlu ijtihad baru oleh para ahli hukum Islam. ${ }^{46}$

Tujuan akhir dilaksanakannya hukum pidana Islam adalah keadilan yang bermakna hakiki. Maksudnya keadilan yang benar-benar adil. Keadilan yang diciptakan oleh manusia belumlah merupakan keadilan yang sebenarnya, tetapi baru keadilan yang bersifat semu. Hanya keadilan yang diciptakan oleh Allah swt sajalah keadilan yang bersifat mutlak. Untuk terciptanya keadilan yang sebenarnya hanya satu landasannya, yakni al-Qur'an yang didukung oleh sunnah rasul. Apabila dasar yuridis dalam kitab suci itu belum ada. Maka, untuk mengisi kekosongan hukum, manusia diwajibkan untuk berijtihad. Artinya, manusia diharuskan berupaya dengan sungguh-sungguh untuk mencari solusi terbaik guna menyelesaikan masalah tersebut. Dengan berbagai rujukan yang telah ada dan daya nalar sebagai analogi untuk berargumen, sesuai dengan keahliannya dalam hukum Islam. Para ahli hukum Islam kontemporer harus bersedia mencurahkan pemikirannya untuk menemukan hukum baru sebagai solusi, mengingat masalah yang dihadapi belum pernah terjadi dimasa rasul dan para sahabat. Namun perlu diingat bahwa ijtihad oleh para ahli hukum Islam tersebut tidak boleh bertentangan atau menyimpang dari ketentuan yang telah ada dalam al-Qur'an dan sunnah.

Menyikapi tentang seponering kasus Bibit Samad Rianto dan Chandra Martha Hamzah dalam pandangan hukum pidana Islam itu adalah adil, mengingat kedua orang tersebut sebagai pimpinan Komisi Pemberantasan Korupsi yang mempunyai tugas berat dan besar. Namun, sebagai muslim memberi catatan khusus bahwa pertama, Bibit Samad Rianto dan Chandra Martha Hamzah harus mengembalikan semua uang hasil korupsi kepada negara. Kedua, Bibit Samad Rianto dan Chandra Martha harus minta maaf kepada publik melalui media dan berjanji tidak akan mengulangi perbuatan itu. ${ }^{47}$

\section{Kesimpulan}

Kebijakan pengesampingan perkara Bibit Samad Rianto dan Chandra Martha Hamzah dilihat dari perspektif hukum Islam, bahwa kebijakan tersebut tidak sesuai dengan prinsip dasar penegakan hukum Islam, yakni menegakkan keadilan terhadap setiap orang. Oleh karena itu, dalam prinsip penegakan hukum Islam siapapun yang melakukan tindak pidana harus dipidana sesuai dengan berat atau ringannya perbuatan yang dilakukan.

Intizar, Vol. 22, No. 1, 2016 
Khusus dalam penegakan hukum pidana $t a^{\prime} z i r$ pengesampingan perkara atau seponering dapat dimungkinkan dan bukan merupakan tindakan yang dilarang. Karena ancaman hukuman terhadap pidana ta'zir ditentukan sepenuhnya oleh penguasa atau 'amir. Oleh karena itu, kasus tindak pidana korupsi Bibit Samad Rianto dan Chandra Martha Hamzah adalah pidana ta'zir, maka diskresi seponering dapat dilakukan.

Kebijakan seponering Bibit Samad Rianto dan Chandra Matha Hamzah belum bersifat final. Oleh karena itu, setiap person atau rech person dapat melakukan upaya hukum sebelum perkara itu kadaluarsa, berupa : 1). Mengajukan gugatan pra peradilan berupa permohonan pembatalan seponering kepada Ketua Pengadilan Tata Usaha Negara, disertai dengan bukti-bukti yuridis bahwa alasan dikeluarkannya tindakan seponering tersebut tidak sesuai dengan kepentingan umum. 2). Mengajukan permohonan pencabutan keputusan tentang seponering tersebut kepada Jaksa Agung dengan alasan bahwa bukti-bukti yang disebutkan dalam konsideran dikeluarkannya keputusan seponering tidak sesuai dengan fakta hukum. 3). Menyelesaikan kasus tersebut dengan restorative justice system, yaitu tersangka tidak perlu menjalani hukuman, akan tetapi harus mengembalikan seluruh hasil korupsi kepada negara dan minta maaf kepada publik.

Intizar, Vol. 22, No. 1, 2016 


\section{Endnote}

1 John M. Echols dan Hassan Shandily, Kamus Inggris Indonesia, (Jakarta: Gramedia, 2010), hlm. 185

2 Bismar Siregar. (2014). Hukum dan Keadilan. http://marginal86kopini.blokspot.com/2013/diskresi-antarakebijkan-dan.html. (21 Januari 2013) (diakses tanggal 2 September 2014)

3 Alviina Treut Burrows. Hukum dan Keadilan, http://marginal 86kopini.blokspot.com/2013/diskresi-antarakebijakan-dan.html (21 Januari 2013) (diakses pada 2 September 2014)

4 JCT Simorangkir, Diskresi Kepolisian (15 Januari 2013) http;//ferli1982./warpress.com /2013/01/15/diskresi-kepolisian (diakses pada 2 September 2014)

5 Thomas J. Aoron, Diskresi Kepolisian (15 Januari 2013) http/ferli1982/warpress.com/2013/01/15/diskresi-kepolisian (diakses pada 2 September 2014)

${ }^{6}$ Kementrian PAN dan Reformasi Birokrasi, Mencari Titik Temu Pengertian Diskresi (7 Maret 2013) http:/www.menpan.go.id/beritaterkini/953-mencari-titiktemu-pengertiandiskresi-dalam-uu-adpem (diakses pada 2 September 2014)

${ }^{7}$ Sudarno, Kamus Hukum, (Jakarta: Gramedia, 2005), hlm. 21

${ }^{8}$ Oetje Rahajoekoesoemah, Kamus Belanda-Indonesia, (Jakarta: Rineka Cipta, 1990), hlm. 308

${ }^{9}$ W. van Hoeve, Kamus Belanda-Indonesia, (Jakarta: Ichtiar Baru, 1986), hlm. 82

${ }^{10} \mathrm{https} / / /$ www.googlr.co.id/?gwsrd=cr\&ei=iLD2vbSIEsqBuQSfuY6YAQ\#q=kamus+ bahasa+Indonesia+latin online (diakses tanggal 14 September 2015)

${ }^{11}$ Detik, Wawancara dengan Ario Setyo, 7 Oktober 2011 (diakses pada 2 Januari 2013)

${ }_{12}$ Tempot, Wawancara dengan Ario Setyo, 7 Oktober 2011 (diakses pada 3 Januari 2013)

${ }^{13}$ Hukum, Wawancara dengan Andi Hamzah, tanggal 24 November 2010 (diakses pada 2 Januari 2013)

${ }^{14}$ Hukum Online, Wawancara dengan Andi Hamzah, tanggal 24 November 2010 (diakses pada 2 Januari 2013)

15 Gozin Siraj, Pengantar Hukum Islam (Sejarah dan Perkembangannya), (Yogyakarta: Fakultas Ekonomi UII, 2007), hlm. 13-18

16 Sultan Hasanal Bolkiah, Arrahman.com.Filter Your mind/get the truth www.arrahmah.com/news/20013/10/24/sekilas-demonstrasi-ontoh-pelksanaan-hukumpidana-syariah-brunai-darussalam-html. (diakses tanggal 1 September 2015)

17 https://www.facebook.com/AlQuranTerjemahDanTafsir/posts/280448928804449, (diakses tanggal 3 Januari 2016)

18 http://ikhwanulmuslimin89.blogspot.co.id/2012/05/qs-al-maidah-ayat-6.html, (diakses tanggal 3 Januari 2016)

19 http://ibnukatsironline.blogspot.co.id/2015/04/tafsir-ayat-surat-al-baqarah-ayat285.html, (diakses tanggal 20 Nopember 2015)

Intizar, Vol. 22, No. 1, 2016 
${ }^{20}$ M. Tahir Azhary, Bunga Rampai Hukum Islam, (Jakarta: IND-HILL-CO, 2003), Hlm 218

21 http://abuabdurrohmanmanado.org/tag/al-anbiya-ayat-107/, (diakses tanggal 12 Nopember 2015)

22 http://anasafrida.blogspot.co.id/2013/02/tafsir-surat-saba-ayat-28.html, (diakses tanggal 12 Nopember 2015)

23 harisudiyono1.blokspot.com/2013/01/kepentingan-umum-bonum-commune,html, (diakses tanggal 2 September 2915)

${ }^{24}$ www.scribd.com.doc/99556368/definisi/kepentingan-umum-menurut-hukum.html (diakses tanggal 15 September 2015)

${ }^{25}$ Gozin Siraj. Pengantar Hukum ..., Op.Cit., hlm. 16

${ }^{26} \mathrm{http}: / /$ tafsirq.com/16-an-nahl/ayat-90, (diakses tanggal 21 Nopember 2015)

${ }^{27}$ Ahmad Abu-al-Wafa, diterjemahkan oleh Asmawi dkk, Hak-hak Pencarian Suaka Dalam Syariat Islam dan Hukum Internasional, (Jakarta: UNHCR dan Fakultas Syariah dan Hukum UIN Syahid, 2011), hlm. 186

${ }^{28}$ Muh \}ammad ibn 'Isa> al-Tirmidhi>, Sunan al-Tirmidhi> wa Huwa al-Ja>mi' alS\}ah\}i>h\}. (Beiru>t : Da>r al-Kutub al-'Ilmiyah, 1435 H./2014 M.), cet. V., 343, Kita>bal-Ah\}ka>m, Ba>b Ma>Ja>a fi> al-Qa>d\}i> Kayfa Yaqd\}i> [3], no. hds. 1327; Bandingkan dengan, Sulaima $>n$ ibn al-Ash'ath al-Sijista $>n i>$, Sunan Abi $>$ Daud. (Beiru>t: Da $>$ r al-Kutub al-'Ilmiyah, 2011), cet. Jld. II., 510, Kita $>b$ al-Aqdiyy $a>t, B a>b$ Ijtih $a>d$, al-Ra'yi> fi> al-Qada>' [11], no. hds. 3592; lihat juga, http://www.alkhoirot.net/2012/07/ijtihad-dalam-islam.html, diakses tanggal 1 Desember 2015

29 Abd. Bin Nuh dan Oemar Bakry, Kamus Arab, Indonesia, Inggris, (Jakarta: Mutiara, t.th), hlm. 70

${ }^{30}$ Rahmat Hakim, Hukum Pidana Islam, (Bandung: Pustaka Setia, 2005), hlm. 12-14

31 http://blitarq-doel.blogspot.co.id/2012/09/hukum-pidana-dalam-islam-jinayat.html, (diakses tanggal 31 Desember 2015)

${ }^{32} \mathrm{http}: / /$ blog.konsultasi-skripsi-tesis-disertasi.org/2013/01/hukum-pidana-islam.html, (diakses tanggal 31 Desember 2015)

${ }^{33}$ Gozin Siraj, Pengantar Hukum ..., Op.Cit., hlm. 41-42

${ }^{34}$ Abd. Bin Nuh dan Omar Bakri, Kamus Arab ..., Op.Cit., hlm. 117

35 https://tafsiralquran2.wordpress.com/2012/11/25/2-188/, (diakses tanggal 1

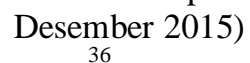

http://mtf-online.com/surah-al-maidah-ayat-42-45-seri-tadabbur-alquran/\#.VmWvZ7-b_VI, (diakses tanggal 2 Desember 2015)

${ }^{37}$ Muh \}ammad ibn 'Isa> al-Tirmidhi>, Sunan al-Tirmidhi > wa Huwa al-Ja>mi' alS\}ah\}i >h\}., 344, Kita>bal-Ah\}ka>m, Ba>b Ma>Ja>a fi>al-Ra>shi> wa al-Murtashi> fi> al-H\}ukm [9], no. hds. 1337

${ }^{38}$ Muh \}ammad ibn 'Isa> al-Tirmidhi>, Sunan al-Tirmidhi> wa Huwa al-Ja>mi' alS\}ah $\{i>h\}$., 344, Kita>bal-Ah\}ka>m, Ba>b Ma>Ja>a fi>al-Ra>shi> wa al-Murtashi> fi> al-H\}ukm [9], no. hds. 1337

${ }^{39}$ Muslim ibn al-Hajja>j al-Qushairi>, S\}ah\}i>h\} Muslim., Jld. II., 191, Kita>b alImmarah,Ba>b Tahlri>m Hadaya> al-'Umma>l [7], no. hds. 1833; lihat juga,

Intizar, Vol. 22, No. 1, 2016 
http://www.walimah.info/pasutri/cara-istri-yang-sedang-haid-memberikan-kepuasan-sekskepada-suaminya/, (diakses tanggal 29 Desember 2015)

${ }^{40}$ Wawancara dengan M. Tahir Azhary, di Perumahan Dosen UI, Ciputat, Tangerang Selatan, (tangggal 11 Maret 2014)

${ }^{41}$ Wawancara dengan Muhammad Tahir Azhary, di Komlek Perumahan Dosen Universitas Indonesia, Ciputat Tangerang Selatan, (tanggal 11 Maret 2014)

${ }^{42} \mathrm{http}$ ://uraianayatalquran-muismahmud.blogspot.co.id/2015/08/terjemahan-surat-albaqarah-ayat-178-sd.htm, (diakses tanggal 2 Desember 2015)

${ }^{43}$ Muh \}ammad ibn 'Isa> al-Tirmidhi>, Sunan al-Tirmidhi > wa Huwa al-Ja>mi' alS\}ah\}i >h\}., 360, Kita>bal-Diyya $>t, B a>b$ Ma $>J a>a$ fi $>H\} u k m i>$ Waliyyi al-Qati $>l i$ fi $>$ al-Qis\}a>s\} wa al-'Afwi>[13], no. hds. 1405; Bandingkan dengan, Muh\}ammad ibn Isma>'i>l al-Bukha>ri>, S\}ah\}i >h\} al-Bukha>ri>., 1247, Kita $>b$ al-Diyya $>t$, Ba $>b$ Man Qutila lahu Qati>lun Fahuwa bi Khair al-Naz\}arain [8],no. hds. 6880.

${ }^{44}$ Muh\}ammad ibn 'Isa> al-Tirmidhi>, Sunan al-Tirmidhi> wa Huwa al-Ja>mi' alS\}ah\}i >h\}., 361, Kita>bal-Diyya $>t, B a>b M a>J a>a$ fi $>H\} u k m i>$ Waliyyi al-Qati $>l i$ fi $>$ al-Qis\}a $>$ s\} wa al-'Afwi>[13], no. hds. 1406

${ }^{45}$ Marsum, Hukum Pidana Islam (Jinayah), (Yogyakarta: Fakultas Hukum UII, 2005), hlm. 105-118

${ }^{46}$ Wawancara dengan Yusrul Ihza Mahendra, di Kantor IHZA \& IHZA Law Firm, Kuningan Jakarta Selatan, tanggal 10 Oktober 2014

${ }^{47}$ Wawancara dengan Marwan Effendy, di Gedung ME Centre, Kuningan Jakarta Selatan, tanggal 24 Maret 2015

\section{Daftar Pustaka}

Abu-al-Wafa, Ahmad. diterjemahkan oleh Asmawi dkk. (2011). Hak-hak Pencarian Suaka Dalam Syariat Islam dan Hukum Internasional. Jakarta: UNHCR dan Fakultas Syariah dan Hukum UIN Syahid.

Alviina Treut Burrows. Hukum dan Keadilan, http://marginal 86kopini.blokspot.com/2013/diskresi-antarakebijakan-dan.html Januari 2013)

Bismar Siregar. (2014). Hukumdan Keadilan. http://marginal86kopini.blokspot.com/2013/diskresi-antarakebijkandan.html. (21 Januari 2013)

Hakim, Rahmat. (2005). Hukum Pidana Islam. Bandung: Pustaka Setia.

http://uraianayatalquran-muismahmud.blogspot.co.id/2015/08/terjemahan-surat-albaqarah-ayat-178-sd.htm,

https://tafsiralquran2.wordpress.com/2012/11/25/2-188/,

http://blog.konsultasi-skripsi-tesis-disertasi.org/2013/01/hukum-pidanaislam.html,

http://blitarq-doel.blogspot.co.id/2012/09/hukum-pidana-dalam-islam-jinayat.html, 
http://mtf-online.com/surah-al-maidah-ayat-42-45-seri-tadabbur-alquran/\#.VmWvZ7-b_VI,

http://anasafrida.blogspot.co.id/2013/02/tafsir-surat-saba-ayat-28.html, http://tafsirq.com/16-an-nahl/ayat-90

Sultan Hasanal Bolkiah, Arrahman.com.Filter Your mind/get the truth www.arrahmah.com/news/20013/10/24/sekilas-demonstrasi-ontohpelksanaan-hukum-pidana-syariah-brunai-darussalam-html.

https://www.facebook.com/AlQuranTerjemahDanTafsir/posts/280448928804449, http://ikhwanulmuslimin89.blogspot.co.id/2012/05/qs-al-maidah-ayat-6.html, http://abuabdurrohmanmanado.org/tag/al-anbiya-ayat-107/,

http://ibnukatsironline.blogspot.co.id/2015/04/tafsir-ayat-surat-al-baqarah-ayat285.html,

harisudiyono1.blokspot.com/2013/01/kepentingan-umum-bonum-commune,html, Hukum Online, Wawancara dengan Andi Hamzah, tanggal 24 November 2010

JCT Simorangkir, Diskresi Kepolisian (15 Januari 2013) http;//ferli1982./warpress.com /2013/01/15/diskresi-kepolisian

John, M. Echols, dan Hassan Shandily. (2010). Kamus Inggris Indonesia. Jakarta: Gramedia.

Kementrian PAN dan Reformasi Birokrasi, Mencari Titik Temu Pengertian Diskresi (7 Maret 2013) http:/www.menpan.go.id/beritaterkini/953mencari-titiktemu-pengertian-diskresi-dalam-uu-adpem

Marsum. (2005). Hukum Pidana Islam (Jinayah). Yogyakarta, Fakultas Hukum UII.

Muslim ibn al-Hajja>j al-Qushairi>, Słah\}i>h\} Muslim., Jld. II., 191, Kita>b alImmarah,Ba>b Tah\}ri>m Hadaya> al-'Umma $>l$ [7], no. hds. 1833; lihat juga, http://www.walimah.info/pasutri/cara-istri-yang-sedang-haidmemberikan-kepuasan-seks-kepada-suaminya/,

Nuh, Abd. Bin dan Oemar Bakry. (t.th). Kamus Arab, Indonesia, Inggris. Jakarta: Mutiara.

Rahajoekoesoemah, Oetje. (1990). Kamus Belanda-Indonesia. Jakarta: Rineka Cipta.

Siraj, Gozin. (2007). Pengantar Hukum Islam (Sejarah dan Perkembangannya). Yogyakarta: Fakultas Ekonomi UII.

Sudarno. (2005). Kamus Hukum. Jakarta: Gramedia.

Tahir Azhary, M. (2003). Bunga Rampai Hukum Islam. Jakarta: IND-HILL-CO.

Intizar, Vol. 22, No. 1, 2016 
Thomas J. Aoron, Diskresi Kepolisian (15 Januari 2013) http/ferli1982/warpress.com/2013/01/15/diskresi-kepolisian

Van Hoeve, W. (1986). Kamus Belanda-Indonesia. Jakarta: Ichtiar Baru.

www.scribd.com.doc/99556368/definisi/kepentingan-umum-menurut-hukum.html Wawancara dengan Ario Setyo. Tempo.

Wawancara dengan Andi Hamzah. Hukum.

Wawancara dengan M. Tahir Azhary, di Perumahan Dosen UI, Ciputat, Tangerang Selatan.

Wawancara dengan Muhammad Tahir Azhary, di Komlek Perumahan Dosen Universitas Indonesia, Ciputat Tangerang Selatan.

Wawancara dengan Yusrul Ihza Mahendra, di Kantor IHZA \& IHZA Law Firm, Kuningan Jakarta Selatan.

Wawancara dengan Marwan Effendy, di Gedung ME Centre, Kuningan Jakarta Selatan. 